\title{
Destination country and export performance of agri-food products during the COVID-19 crisis
}

\section{Valeska V. Geldres-Weiss* and Natalia B. Arcos-Pino}

Department of Management and Economics, Faculty of Law and Business, Universidad de La Frontera, Francisco Salazar 01145, 4811230, Temuco, Chile Email: valeska.geldres@ufrontera.cl Email: natalia.arcos@ufrontera.cl *Corresponding author

\section{Skania L. Geldres-Weiss}

Department of Economic and Business, Faculty of Social Sciences, Business and Law, Universidad de La Serena, Amunátegui s/n, 1700000, La Serena, Chile Email: skania.geldres@userena.cl

\section{Pedro E. Guerrero-Stuardo}

Department of Management and Economics, Faculty of Law and Business, Universidad de La Frontera, Francisco Salazar 01145, 4811230, Temuco, Chile Email: pedro.guerrero@ufrontera.cl

\begin{abstract}
In the context of markets with uncertainty, we use the stakeholder theory to explain the role and importance of destination country in the export arena. We analysed six cross-sectional Chilean case studies on exported agri-food products in three categories (fresh, frozen, and processed). Using quantitative and qualitative data, destination countries and export performance were analysed, comparing 2020 (during the COVID-19 crisis) with the previous year. Our results show that exported agri-food products maintained their main destination countries, and maintained or increased the number of destination countries. The analysis of export performance shows that export performance varies depending on both the kind of product and the category to which it belongs. The role of trade agreements confirmed the destination country as a primary stakeholder. This study thus contributes to the stakeholder theory and literature on export performance, considering the destination country as a primary stakeholder in exporting firms.
\end{abstract}

Keywords: export performance; destination country; exports; stakeholder theory; agri-food products; COVID-19; developing country; Chile. 
Reference to this paper should be made as follows: Geldres-Weiss, V.V., Arcos-Pino, N.B., Geldres-Weiss, S.L. and Guerrero-Stuardo, P.E. (2021) 'Destination country and export performance of agri-food products during the COVID-19 crisis', Int. J. Export Marketing, Vol. 4, No. 3, pp.208-228.

Biographical notes: Valeska V. Geldres-Weiss is an Associate Professor in Marketing at Universidad de La Frontera in Chile. She earned her PhD in Business Administration and Marketing from Seville University, Spain and completed a Postdoctoral Program at the University of Sao Paulo, Brazil. She is a member of Research Center on International Challenges at Universidad de La Frontera. Her research interests are international business and international marketing in the scope of firm's export activity. She has published in prestigious journals such as Business Research Quarterly, Contemporary Economics, International Journal of Export Marketing, Journal of Business Research, Journal of International Management, Journal of Promotion Management, and Sustainability.

Natalia B. Arcos-Pino is a research assistant at Universidad de La Frontera in Chile. Currently she is working in Canada as a Trade Advisor at Trade Commission of Chile in Toronto. Between 2018 and 2020, she was the Head of South America and Pacific Alliance Department at ProChile in Chile. She obtained her degree in Business Administration in 2017 from the Universidad de La Frontera. She has almost four years of experience in international business promotion in Spain, South America and Canada.

Skania L. Geldres-Weiss is a researcher at Department of Economics and Business at Universidad de La Serena in Chile, and international marketing consultant. She is an Agronomist Engineer and has a Master's degree in Business Administration, and is a Doctoral candidate in Marketing at Valencia University. She has experience in international business in the food industry in the world, prospecting, promoting, and maintaining international markets for Chilean companies. For 15 years, she was in charge of international sales, and the development of international marketing strategies in the B2B arena.

Pedro E. Guerrero-Stuardo is a research assistant at Universidad de La Frontera in projects related to export competitiveness and export promotion. $\mathrm{He}$ is a member of Research Center on International Challenges at Universidad de La Frontera. He obtained his degree in Business Administration in 2020 from the Universidad de La Frontera. He has experience as a research assistant for three years, mainly dedicated to data analysis, collaborating on five scientific publications. Currently, he works at Business Clinic of Universidad de La Frontera, providing free advice to micro entrepreneurs. Also, he was a tutor for four years in the Economic Clinic at the same university.

\section{Introduction}

Due to the global crisis of COVID-19, the World Trade Organization (WTO) forecasts a possible decrease in global trade volume from $13 \%$ to $32 \%$; and notes that it can be expected to be even more negative in terms of value due to falling prices (WTO, 2020). However, as a vital sector, agricultural trade will be less affected, from $12 \%$ to $20 \%$, in commercial value. The availability of agri-food products, according to Ker and Cardwell (2020), will depend on COVID-19 effects on health, trade, transportation, and farm's 
financial stability. In this context, Hobbs (2020) stated that trust in supply chain partners could be built through collaborative relationships and flexibility in response to unexpected changes in the market. The role of government and policy makers is critical in supporting supply chains, as well as considering the agri-food businesses as essential (Hobbs, 2020).

According to Donthu and Gustafsson (2020), COVID-19 has led to dramatic changes in how businesses not only act and consumers behave in a network of actors (i.e., firms, customers, and public organisations), but it has also shown that markets are dynamic and can move rather rapidly.

Schembri et al. (2019) highlighted the participation of the government in export promotion, as a stakeholder, through market intelligence and commercial networks. As a primary stakeholder, the government has a direct and significant impact on the organisation, and their participation is essential for the company's operation (Schembri et al., 2019). Clarkson (1995), Agle et al. (1999), and Park and Ghauri (2015) defined government as a primary stakeholder. Clarkson (1995) indicated that there is a high level of interdependence between the organisation and its primary stakeholder groups. This author included the government in the public stakeholder group, which provides infrastructures, markets, laws and regulations. In this study we use Freeman's (1984) stakeholder definition following other authors such as Schembri et al. (2019), Agle et al. (1999), and Clarkson (1995). In international business, the government provides regulations (Clarkson, 1995), such as the free trade agreements (FTA), which are vital for exporting companies (Hejazi et al., 2017). Thus, in concordance with Schembri et al. (2019), this study is based on the stakeholder theory and it analyses the destination country and the product export performance of agri-food exporting companies. FTAs create networks of trust and collaboration, allowing commercial opportunities for exporting companies abroad and greater possibilities for export performance.

On the other hand, Donthu and Gustafsson (2020) stated that COVID-19 poses a unique opportunity to study change in the markets within a very limited time span, and how societies today rely on the importation of important products.

Considering the above, the aim of this research is to shed light on the determinants of firm export activity, focusing on the role of destination country as a primary stakeholder in agri-food exporting companies.

This article focuses on two research questions. First, whether COVID-19 encourages food exporting firms to maintain or increase their trade partners (main destination country; number of destination countries, which concentrate $90 \%$ of export value; and the total number of destination countries). Second, whether agri-food product exports performance (prices, quantity, and export value) will be maintained or increased during the COVID-19 crisis. To answer these research questions, we compared the destination country and export performance of exported agri-food products during 2020 (during the COVID-19 crisis) with the previous year (2019).

Due to the need to extend the literature and to study this 'emerging' topic (Donthu and Gustafsson, 2020; Pantano et al., 2020; Sheth, 2020), we chose the case study method. This research used multiple cross-sectional case studies in order to analyse the agri-food sector, which has different types of food and categories of products (fresh, frozen, and processed).

The present study focused on exported agri-food products from Chile, an emerging market in Latin America, with a strong emphasis on firm internationalisation and a 
network of 28 trade agreements, the pillars of extensive bilateral and multilateral business relations (SUBREI, 2020).

For the cases studied we used quantitative and qualitative data. The quantitative data sources of destination countries and export performance of six exported agri-food products cases were based on the International Trade Centre (ITC) database (trademap.com). The qualitative data were obtained from media and web pages, as well as interviews with key company executives.

This study contributes to the literature in several ways. First, this study contributes to the stakeholder theory by unveiling the destination country as a stakeholder, following previous works who define the government as primary stakeholder (Schembri et al., 2019; Clarkson, 1995; Agle et al., 1999; Park and Ghauri, 2015). This is the first time, as far as we know, in which the destination country is analysed as a primary stakeholder in the international business context, and so, it adds to Schembri's previous study, which analysed the home country as a primary stakeholder in government export promotion. This study also highlights the relevant participation of the government in export activities in signing international trade agreements. Second, our findings contribute to the study of the impact of COVID-19 on exports within the agri-food sector that is considered essential at a global level. Third, this study used data from an emerging and very export-oriented market, Chile in Latin America, which only a few studies have analysed (Bianchi et al., 2018). Finally, we showed that the change in the markets can be studied within a very limited time span (Donthu and Gustafsson, 2020).

\section{Theoretical framework}

\subsection{Stakeholder theory}

The stakeholder is defined as "any group or individual who can affect or is affected by the achievement of the organisation's objectives" [Freeman, (1984), p.46]. In addition, the stakeholders were classified by Clarkson (1995) in primary and secondary groups. In this sense, the literature defines government as a primary stakeholder (Clarkson, 1995; Agle et al., 1999; Park and Ghauri, 2015; Schembri et al., 2019). Also, the primary stakeholder group has a direct and significant impact on the organisation, and their participation for the company operation is essential (Schembri et al., 2019). According to Clarkson (1995), the government is part of the public stakeholder group. Specifically, governments "provide infrastructures and markets, whose laws and regulations must be obeyed, and to whom taxes and other obligations may be due" [Clarkson, (1995), p.106].

The role of the government in the business context is confirmed by Dahan et al. (2015). These authors changed the status of the government, from a non-stakeholder entity to a stakeholder one; namely, to a business partner. From this stance, the findings of Schembri et al. (2019) confirmed the relevance of the home country government as a primary stakeholder. Also, Schembri et al. (2019) highlighted the participation of the government in export promotion through market intelligence and commercial networks. Similarly, Dang et al. (2020) pointed out that the government is a key stakeholder for multinational enterprises.

Additionally, within international business, destination countries are particularly assisted by the ITC, which developed a suite of online tools to make global trade more transparent, providing access to markets through market intelligence and international 
commercial networks (ITC, 2021). These online tools enable business actors to identify export opportunities and compare market-access requirements (ITC, 2021). At the same time, the global trade helpdesk (GTH) initiative gives the opportunity to compare the demand for products across markets, explore tariffs, and access market conditions, among others.

\subsection{Destination country}

In the context of markets with uncertainty, the latter can be diminished by increasing the interaction and integration of the markets (Johanson and Vahlne, 1977). According to Cadogan et al. (2002), in order to reduce the risks associated with exports, for instance in the case of exporting companies with a high level of dependence on exports, it is important that the firms are sensitive to the changes that occur in the export environment. On the other hand, enhancing the firm's exports, networks and networking, and their quality, are key activities in foreign markets (Coviello and Munro, 1995; Ismail and Kuivalainen, 2015; Conti et al., 2014; Sraha et al., 2020). Furthermore, in order to maintain international business partners, the commitment to foreign markets, highlighting the acquisition of knowledge, and experience in these markets, is essential (Johanson and Vahlne, 1977).

In relation to the agri-food industry and COVID-19, Barichello (2020) pointed out that several implications of the pandemic in international trade apply in most countries. First, it is possible that income decreases. Second, it is expected that the import of food from developing countries will decline the most, with more modest declines coming from rich countries. Third, smaller declines are expected in the demand for food imports compared to possible declines in total trade flows as a general trend. Fourth, in the case of developing countries that generally export their food production to rich countries, it can be expected that the results for those developing countries will not be so dramatic. In some high-income countries, such as Canada, the biggest concerns for the agricultural and food sector appear in the long term, when the viability of fresh food depends on foreign producers (Ker and Cardwell, 2020).

In these uncertain times brought about by the COVID-19 pandemic, the impact on the food industry was analysed by Nakat and Bou-Mitri (2020), who emphasised the importance of maintaining the trust of customers and partners, as they are the key to success. This is further supported by Gulati (1995), who stated that organisations with prior common history tend to trust each other. In this sense, agreements between countries that drive tariff liberalisation enhance the entry of agri-food products into destination countries (Hejazi et al., 2017). The country's reputation is also relevant in order to sign trade agreements, allowing these agreements to increase exports to destination countries (Dimitrova et al., 2017).

Hence, in the future, there may be a desire to strengthen international cooperation to aid in keeping supply chains operating in times of crisis (Kerr, 2020). These arguments led us to propose the following hypothesis:

H1 The COVID-19 crisis encourages food exporting firms to maintain or increase their trade partners. 


\subsection{Export performance}

Lages et al. (2009) proposed a broader conceptualisation and operationalisation of export performance that recognises the contribution of key external network partners to the firm, and not just one that focuses on internal stakeholders. The authors highlighted the importance of a network of ties in an international business context. Lages et al. (2009) also highlighted the need for the development of export literature centring on different stakeholder and network groups involved in exporting. In fact, Barney (2018) pointed to the potential role of stakeholders in performance-enhancing behaviours. In this regard, an FTA positively influences export performance (Na and Yoon, 2011). Indeed, according to Baier and Bergstrand (2007), an FTA could double the international trade between two countries in ten years.

In the context of agri-food products, COVID-19 has brought a substantial disruption to agricultural markets (Orden, 2020). In markets with uncertainty, Lu et al. (2010) found a negative relation between uncertainty and a firm's international performance, confirming previous findings. In addition, Orden (2020) stated that the international supply chain bottleneck problems during COVID-19 times could put a downward pressure on cereal prices. At the same time, Lin and Zhang (2020) found that on average agricultural businesses experienced declines in exports. However, these authors also state that exports of some agri-food products related to staple food had an increase in exports. Contrary to this, Hailu (2020) stated that the food processing industry has seen a decline in export and import activity. Nevertheless, the latter author also affirmed that the impact of COVID-19 may depend on the type of export product. This rationale led us to hypothesise the following:

H2 Export performance of agri-food products will be maintained or will increase in the COVID-19 crisis.

\section{Methodology}

\subsection{Research design}

The design of this research is observational-descriptive-cross-sectional. We use multiple cross-sectional case studies in order to analyse the agri-food sector which has different and varied food products and categories (fresh, frozen, and processed). The unit of analysis is the exported agri-food product.

Case studies have been used in several areas of international business research (Vissak, 2010; Vissak et al., 2020; Nummela et al., 2020) and is a very useful method to understand how and why certain events have unfolded in a certain way (Yin, 1994). Vissak (2010) stated that the case study can explain new and complex issues, explaining 'how' and 'why' (not) questions about a set of events, providing an holistic perspective on real-life events and the processes leading to certain results. 
According to Donthu and Gustafsson (2020), COVID-19 has had severe economic consequences across the globe, which have led to dramatic changes in how businesses act and consumers behave. These authors highlighted that COVID-19 has shown us that markets can move rapidly, and COVID-19 allows study of the changes in markets within a very short time span. Thus, due to the need to extend the literature and study of this 'emerging' topic (Donthu and Gustafsson, 2020; Pantano et al., 2020; Sheth, 2020), we chose the case study method.

\subsection{Cases selection}

In order to select the cases, convenience or directed sampling was used. The choice of cases was based on the exported agri-food products from the South of Chile.

For the selection of the cases, an analysis of exported agri-food products from southern Chile was carried out considering three regions: La Araucanía, Los Ríos, and Los Lagos. In the context of foods, these regions are characterised by their production and export of agri-food.

The quantitative data source for the case selection was datasur.com, which has information about Chilean export transactions and is able to identify the region of origin of the exported products. The analysis of the exported agri-food products was based on the international classification of the harmonised system (HS) code. For each of these regions, agri-food exports were analysed, considering all products exported under HS chapters 02 to 24, at a six-digit level (subheadings HS code). This process identified the main exported agri-food products which were selected for the study.

The cases selected were: salmon, fruits, oat cereals, dairy products, meat, and other foods. These six cases included 19 exported agri-food products (see Table 1). These products are included in seven HS chapters (see Table A1), and represent 54 and 53\% of the total Chilean food export value in these HS chapters, and were exported by 928 and 842 companies, in 2019 and 2020 respectively (see Table A2).

\subsection{Data sources and analysis}

This study used quantitative and qualitative data. The data source of destination countries and export performance of 19 agri-food products selected, was the ITC database (trademap.com), where each product was analysed alongside the international classification of the HS code with six-digits of HS-code. The total Chilean exports of each of the 19 exported agri-food products were identified: export unit value, quantity value, export value, and destination countries, for each year of study, 2019 and 2020.

The variables studied, obtained from trademap, were the following:

- $\quad$ export product: product specification in the HS with six digits

- main destination country: country that accounts for the largest percentage of exports of a given product

- number of countries that concentrate $90 \%$ of export value: number of destination countries covering $90 \%$ of each exported product

- total number of destination countries: number of destination countries for each product 
- $\quad$ export unit value: price for each product, in US Dollars per ton

- $\quad$ export quantity: quantity exported in tons

- $\quad$ export value: export unit value multiplied by export quantity, in thousand US dollars.

For quantitative and qualitative data analysis, descriptive statistics were used for which absolute frequencies and percentage frequencies were determined. For the analysis and interpretation of the data, information was obtained from the media and information from formal web pages and experts in food exports, as well as interviews with key executives of companies in the southern region of the country. The two companies interviewed corresponded to the frozen beef and processed fruit sectors.

\section{Results}

\subsection{Destination countries of exported agri-food products}

The results show that most of the exported agri-food products maintained its main destination country in terms of total export value (17), however, 11 products decreased their export value to these countries. Also, maintained or increased the number of destination countries that concentrate $90 \%$ of total export value (13) and total number of destination countries (13) (see Table 1).

All the destination countries of the exported agri-food products analysed, except Russia, have trade agreements in force with Chile allowing a tariff of $0 \%$ (see Table 2). In the case of Russia, the Chile-European Community Association Agreement, in force since 2003, allows Chile to access a tariff reduction by the Global System of Trade Preferences (GSTP) among developing countries.

In times of COVID-19, the results of cases analysed show that the exported agri-food products maintained their main destination country, and also maintained or increased the number of destination countries. This led us to accept hypothesis H1, which suggests that COVID-19 encouraged food exporting firms to maintain or increase their trade partners.

\subsection{Export performance of exported agri-food products}

The variables of export performance analysed were export unit value, export value, and export quantity. The analysis of export performance was carried out in two ways, by case and category.

The cases of fruit, meat, oat cereal, and other foods showed the best results, increasing their export value, and export quantity in 2020 compared with 2019, highlighting processed oats and frozen bovine meat with bone in. On the other hand, the salmon and the dairy products showed the worst results, decreasing their export value in 2020 compared with 2019 (see Table 3).

In the case of salmon, most of the prices and export value decreased, but most of the export quantity increased in 2020 compared with 2019. The COVID-19 impact on fresh salmon export performance was greater than on frozen salmon. This impact could be related to both the sanitary measures imposed in the HoReCa channel (Salmonexpert, 2021) and with the general impact of COVID-19 in the fish sector (FAO, 2019). 
Table 1 Destination countries of exported agri-food products

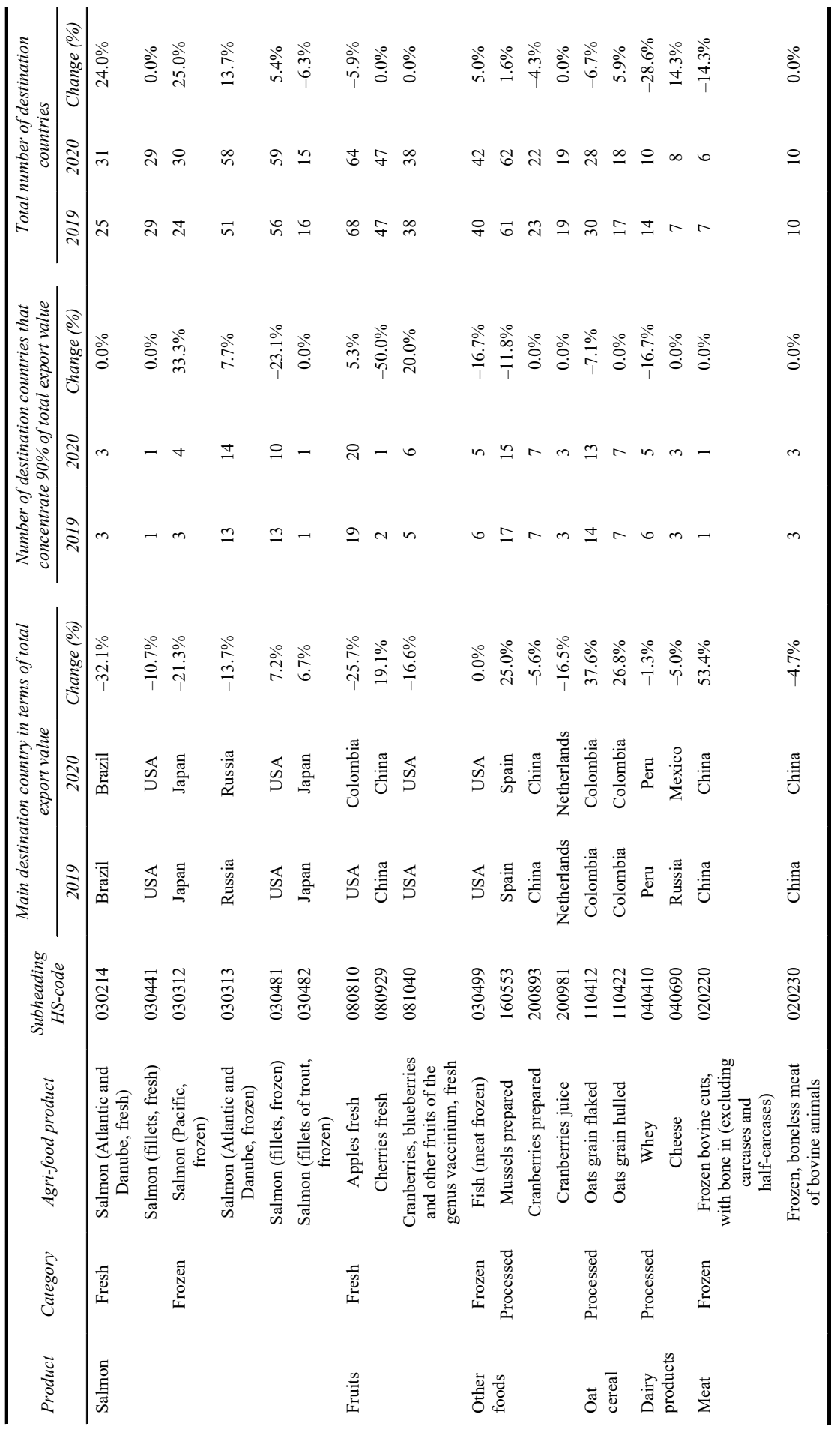


Table 2 Trade agreements with main destination countries of exported agri-food products

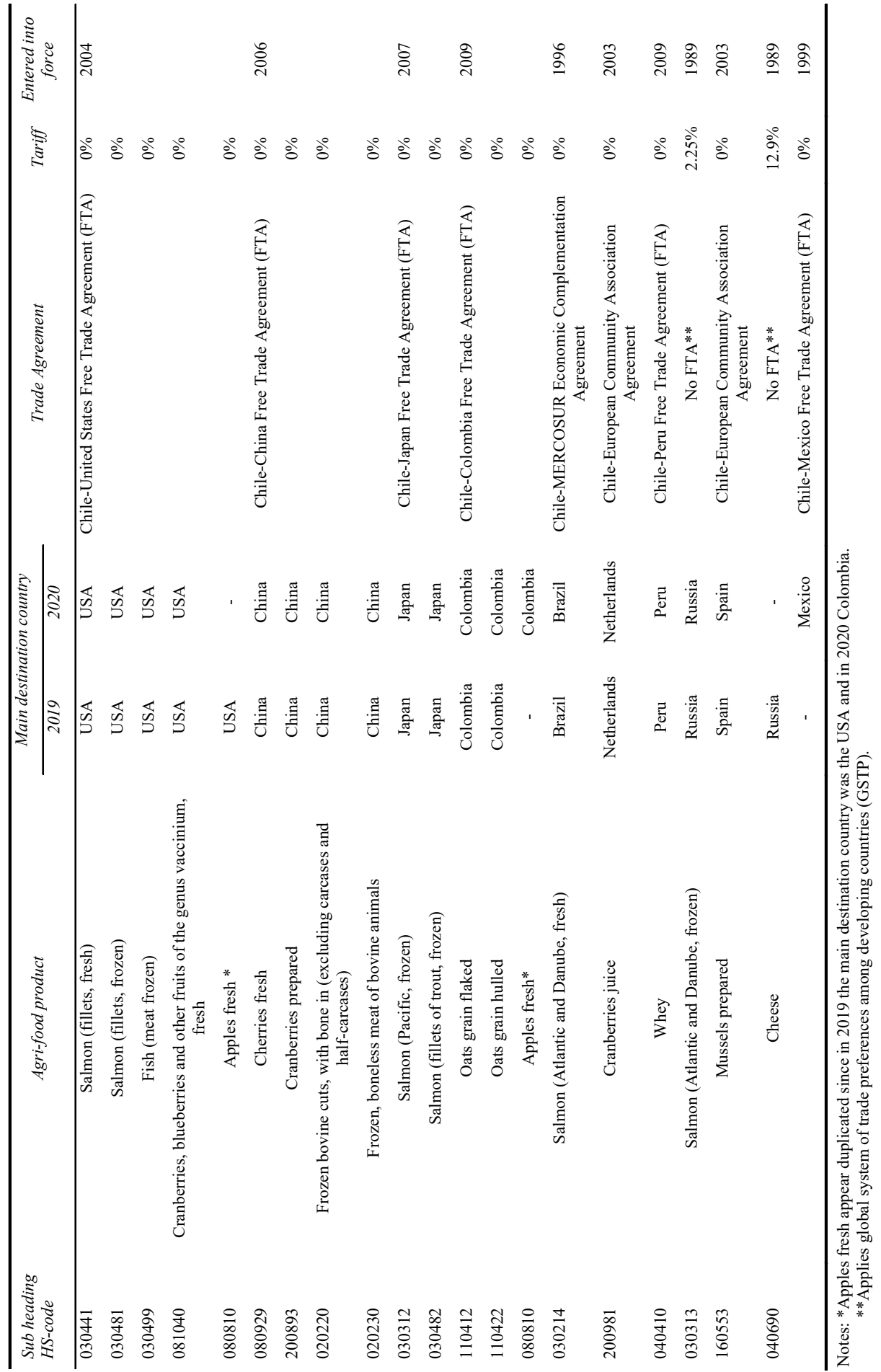


Table 3 Export value and quantity of exported agri-food cases

\begin{tabular}{|c|c|c|c|c|c|c|c|}
\hline \multirow{2}{*}{ Product } & \multirow{2}{*}{$\begin{array}{c}\text { Subheading } \\
\text { HS-code }\end{array}$} & \multicolumn{3}{|c|}{ Export value US dollar thousand } & \multicolumn{3}{|c|}{ Export quantity tons } \\
\hline & & 2019 & 2020 & Change & 2019 & 2020 & Change \\
\hline Salmon & $\begin{array}{l}\text { 030214, } \\
030312, \\
030313, \\
030441, \\
030481, \\
030482\end{array}$ & $4,443,329$ & $3,758,977$ & $-15.4 \%$ & 647,791 & 707,800 & $9.3 \%$ \\
\hline Fruits & $\begin{array}{c}080810 \\
080929 \\
081040\end{array}$ & $2,247,288$ & $2,330,591$ & $3.7 \%$ & $1,124,023$ & $1,116,466$ & $-0.7 \%$ \\
\hline $\begin{array}{l}\text { Oat } \\
\text { cereal }\end{array}$ & $\begin{array}{l}110412 \\
110422\end{array}$ & 90,520 & 131,984 & $45.8 \%$ & 187,629 & 221,534 & $18.1 \%$ \\
\hline Meat & $\begin{array}{c}020220 \\
020230\end{array}$ & 74,137 & 90,338 & $21.9 \%$ & 19,529 & 24,392 & $24.9 \%$ \\
\hline $\begin{array}{l}\text { Other } \\
\text { foods }\end{array}$ & $\begin{array}{l}030499, \\
160553, \\
200893, \\
200981\end{array}$ & 630,464 & 673,515 & $6.8 \%$ & 131,213 & 145,588 & $11.0 \%$ \\
\hline $\begin{array}{l}\text { Dairy } \\
\text { products }\end{array}$ & $\begin{array}{l}040410, \\
040690\end{array}$ & 51,758 & 42,487 & $-17.9 \%$ & 25,552 & 22,626 & $-11.5 \%$ \\
\hline Total & & $7,537,496$ & $7,027,892$ & $-6.8 \%$ & $2,135,737$ & $22,38,406$ & $4.8 \%$ \\
\hline
\end{tabular}

Regarding fresh fruits studied, the cherry was the only one that reported positive values in the three export performance indicators in 2020 compared with 2019, highlighting an increase of $9.1 \%$ in the price and $5.5 \%$ in the quantities exported (see Table A3). This positive export performance could be related to the first part of the Chilean cherry season (November and December 2020) that represented attractive price levels achieved in wholesale markets. Also, this was mainly due to a controlled level of arrivals, which did not put pressure on the market, demand recovering from the effects of the pandemic and the good quality of the Chilean offer (iQonsulting, 2021a); in addition, by the efforts of the Chilean producers and exporters, who are members of the 'Cherry committee' and are committed to supplying a safe and healthy product (ASOEX, 2020). Fresh apples, cranberries and blueberries all decreased their export value between $5.7 \%$ and $7.8 \%$ (see Table A3), due to lower prices and lower quantities exported, in 2020 compared with 2019. The negative export performance of the apples could be related to the drought, that resulted in medium to small sizes. Also, COVID-19 caused a strong contraction of the markets, altering the flows and marketing prices, and an increase in the participation of New Zealand to the detriment of Chile (iQonsulting, 2021b). The negative export performance of blueberries could be related to the pressure generated by the growth of the supply of blueberries worldwide which has been reflected in the fall in prices (iQonsulting, 2020b).

In respect of grain hulled and grain flaked oats (HS 110412 and HS 110422), both processed, increased their export performance in 2020 compared with 2019. Specifically, their export value increased by 44.9\% (HS 110412) and 46.9\% (HS 110422) (see Table A3). The positive export performance could be explained by the fact that they are a 
relevant source of cheap protein and by the fear of shortages caused by COVID (Revista del Campo, 2020).

Respecting meat, specifically frozen bovine cuts, with bone in (HS 020220) increased its export performance indicators in 2020 compared with 2019, increasing its export value by $54 \%$ (see Table A3). This positive result could be related to the Chilean integrated system of animal health, traceability of livestock, and an official inspection system in exporting livestock establishments (Portal Agrochile, 2020). However, frozen boneless beef (HS 020230) had negative results on all indicators (see Table A3).

In the case of other foods, processed mussels (HS 160553) highlighted positively all export performance indicators in 2020 compared with 2019, increasing its export value by $22.9 \%$ in 2020 compared with 2019 (see Table A3). Also, prepared cranberries (HS 200893 ) increased their export value by $21.3 \%$ and their export quantity by $23.6 \%$, despite a 1.9\% drop in price in 2020 compared with 2019 (see Table A3). The cranberries results could be related to the worldwide trend for foods classified as superfood, which boomed in the retail categories (New Hope Nature Media, 2020). The company that produces and exports prepared cranberries (HS 200893) in Chile stated that its final consumers are attracted by the characteristics of their cranberry products, which are known worldwide as superfood. The COVID-19 impact has been positive for the company, increasing demand and sales from its customers worldwide. In addition, the positive export value of prepared cranberries could have been obtained due to their sales consolidation in the Netherlands, the main entrance to the European Union, along with the worldwide trend for foods classified as superfood.

Finally, regarding dairy products, whey and cheese (HS 040410 and HS 040690) decreased their export performance indicators in 2020 compared with 2019, reducing their export value by $14.5 \%$ and $19.2 \%$ respectively (see Table A3). This negative result could be explained by international prices and COVID-19 effects (ODEPA, 2020).

In the analysis by category (fresh, frozen, and processed), the fresh category showed the worst results, decreasing its export quantity, and export value in 2020 compared with 2019. Nevertheless, the frozen category increased its export quantity, and decreased its export value in 2020 compared with 2019. On the other hand, the processed category showed the best results, increasing its export value, and export quantity in 2020 compared with 2019 (see Table 4).

Regarding the fresh category, fresh Atlantic and Danube salmon (HS 030214), was the most affected in terms of all export performance indicators, decreasing by $38.2 \%$ of its export value in 2020 compared with 2019. Also, fresh salmon fillets (HS 030441) decreased its export price, and export value, despite increasing export quantity by $11.9 \%$, in 2020 compared with 2019. The negative export performance of the fresh salmon could be explained by the consequences of the COVID-19 on the tourism sector. According to the Executive Director of the Salmon Council: "...the fall in the value of shipments reflects the impact of the sanitary measures imposed by the pandemic, such as closure and confinement, on sales in the HoReCa channel, which represents a considerable percentage of salmon sales". This phenomenon had a greater impact on fresh salmon than on the frozen category (Salmonexpert, 2021).

With regard to the frozen category, most frozen products increased their export quantity in 2020 compared with 2019. Nevertheless, most frozen products decreased in their export prices, achieving lower exported unit values in 2020 compared with 2019. The exceptions were frozen bovine cuts with bone in (HS 020220), and frozen salmon trout fillets (HS 030482), increasing their export value, despite a drop in price, thanks to 
an increase in export quantity. The positive export performance of frozen bovine meat could be explained because Chile is known as a supplier of quality food, with an integrated system of animal health, traceability of livestock and an official inspection system in exporting livestock establishments. Thus, Chile provides guarantees to third countries for compliance with their regulations, which is reflected in the opening of various markets that have been remained open for years (Portal Agrochile, 2020). One of the export companies interviewed, which processes and exports frozen bovine meat, stated that COVID-19 brought an important effect on costs and investments: it doubled the cost of transportation, while it also developed protocols consisting of testing and constant monitoring of the people inside and outside the production plant. In pandemic times, the production level remained the same but with much more effort from, workers, managers, suppliers and distributors.

Table 4 Export value and quantity of agri-food cases by category

\begin{tabular}{|c|c|c|c|c|c|c|c|c|}
\hline \multirow[t]{2}{*}{ Category } & \multirow{2}{*}{ Product } & \multirow{2}{*}{$\begin{array}{l}\text { Subheading } \\
\text { HS-code }\end{array}$} & \multicolumn{3}{|c|}{$\begin{array}{c}\text { Export value US dollar } \\
\text { thousand }\end{array}$} & \multicolumn{3}{|c|}{ Export quantity tons } \\
\hline & & & 2019 & 2020 & Change & 2019 & 2020 & Change \\
\hline \multirow[t]{2}{*}{ Fresh } & Salmon & $\begin{array}{l}030214 \\
030441\end{array}$ & $2,119,642$ & $1,629,821$ & $-23.1 \%$ & 303,225 & 303,338 & $0.0 \%$ \\
\hline & Fruits & $\begin{array}{c}080810 \\
080929 \\
081040\end{array}$ & $2,247,288$ & $2,330,591$ & $3.7 \%$ & $1,124,023$ & $1,116,466$ & $-0.7 \%$ \\
\hline \multirow[t]{3}{*}{ Frozen } & Salmon & $\begin{array}{l}030312, \\
030313, \\
030481 \\
030482\end{array}$ & $2,323,687$ & $2,129,156$ & $-8.4 \%$ & 344,566 & 404,462 & $17.4 \%$ \\
\hline & Meat & $\begin{array}{l}020220 \\
020230\end{array}$ & 74,137 & 90,338 & $21.9 \%$ & 19,529 & 24,392 & $24.9 \%$ \\
\hline & $\begin{array}{l}\text { Other } \\
\text { foods }\end{array}$ & 30499 & 391,444 & 387,942 & $-0.9 \%$ & 37,206 & 38,574 & $3.7 \%$ \\
\hline \multirow[t]{3}{*}{ Processed } & $\begin{array}{l}\text { Oat } \\
\text { cereal }\end{array}$ & $\begin{array}{l}110412 \\
110422\end{array}$ & 90,520 & 131,984 & $45.8 \%$ & 187,629 & 221,534 & $18.1 \%$ \\
\hline & $\begin{array}{c}\text { Dairy } \\
\text { products }\end{array}$ & $\begin{array}{c}040410 \\
040690\end{array}$ & 51,758 & 42,487 & $-17.9 \%$ & 25,552 & 22,626 & $-11.5 \%$ \\
\hline & $\begin{array}{l}\text { Other } \\
\text { foods }\end{array}$ & $\begin{array}{c}160553 \\
200893 \\
200981\end{array}$ & 239,020 & 285,573 & $19.5 \%$ & 94,007 & 107,014 & $13.8 \%$ \\
\hline
\end{tabular}

Respecting the processed category, most products increased their export value and export quantity in 2020 compared with 2019, except for dairy products. In the case of oats cereal (grain hulled and grain flaked oats), they increased their export value and export quantity in 2020 compared with 2019. This positive export unit value could have been provided by the high interest in buying oats on the international markets, since it represents a significant source of cheap protein; together with the fear of shortages caused by COVID-19, pushing importers to buy oats that were available on the international market (Revista del Campo, 2020). 
This category also highlighted prepared mussel which increased on all export performance indicators, achieving an increase in the export value of $22.9 \%$ in 2020 compared with 2019 (see Table A3).

The analysis of export performance by cases and category shows that the final export performance varies depending on both the kind of product and the category to which it belongs. In this context the most important features in these times of COVID-19 are market channel, nutritional and health characteristics, storage and storage shelf life, transportation, sanitary confidence, and the product category (fresh, frozen, processed).

For the six exported agri-food products cases studied, the results show that in most cases studied there was an increase in export performance in 2020 compared with 2019 , and this is also present in the processed category. But some cases decreased their export performance, as is the case with salmon and dairy products, as well as fresh products. These results led us to accept partially hypothesis H2, which proposed that agri-food products either maintained or increased their export performance during the COVID-19 crisis.

\section{Discussion and conclusions}

The COVID-19 pandemic has brought severe economic consequences at global level driving changes in how businesses act and consumers behave (Donthu and Gustafsson, 2020). These authors stated that countries have limited the movement of their citizens by confining them to their homes and closing their borders, with serious effects. First, the tourism and travel industries were deeply affected. Second, expos, conferences, large gatherings and events were called off. Third, countries started to stockpile food, equipment, and medicine. Finally, countries are preparing to produce them locally, in order to avoid impaired access in the future.

In this context, we have examined destination countries and export performance of six cases of exported agri-food products from Chile.

The hypotheses have been drawn from arguments built from the stakeholder theory, for which we have found empirical support. We found that, for the six exported agri-food products cases studied, in times of COVID-19 the food exporting companies maintained or increased their trade partners, and export performance. These findings resonate with calls in the literature for the need to extend the study of this 'emerging' topic, that is COVID-19 (Donthu and Gustafsson, 2020; Pantano et al., 2020; Sheth, 2020) and with calls for the study of products related to food (Lin and Zhang, 2020).

Our study shows that COVID-19 has encouraged food exporting companies to maintain or increase their trade partners, as well as confirming the importance of networks and networking as such, and their quality for export companies in their activities in foreign markets (Coviello and Munro, 1995; Ismail and Kuivalainen, 2015; Conti et al., 2014; Sraha et al., 2020). The study also endorses that, in the agri-food world industry, exports of agri-food products from a developing country towards rich countries can be expected not to decline so dramatically (Barichello, 2020). In this sense, the main destination countries regarding export value in this study, are the USA and Japan. The findings also show the importance of maintaining the trust of partners in the food industry (Nakat and Bou-Mitri, 2020; Gulati, 1995). In fact, this trust and the prior common history are reflected in the trade agreements signed between Chile and the main destination countries of the products exported. 
In the six cases studied, the findings show that most of the cases maintained their main destination country in 2020 compared with 2019, supporting Johanson and Vahlne's claims (1977). Regarding, export performance varied according to the characteristics of each product (Hailu, 2020). However, the analysis by cases showed that most of the cases increased or maintained their export performance in times of COVID-19. Indeed, in times of COVID-19, the results show the importance of staple foods, such as oats processed and bovine meat (Lin and Zhang, 2020). Additionally, the results highlighted products with therapeutic value such as superfoods (Ker and Cardwell, 2020; New Hope Nature Media, 2020). Finally, the results show the HoReCa chain as the most affected under social confinement due to COVID-19 within the agri-food product chain.

Also, we found that export performance of agri-food products in times of COVID-19 is related to product features such as transportation (Ker and Cardwell, 2020; Vasylieva and James, 2021), nutritional and health characteristics (Vasylieva and James, 2021; Ker and Cardwell, 2020), storage difficulties and storage shelf life (Vasylieva and James, 2021), and value added (Vasylieva and James, 2021). Thus, export performance not only depends on the type of exported product (Hailu, 2020), but also on its category, whether it is fresh, frozen, or processed.

\section{Implications for theory}

The paper contributes to the stakeholder theory and export performance literature in the analysis of the destination countries as a primary stakeholder of the exporting firms, analysing the influence of COVID-19 on destination countries and export performance in the light of the export products' level.

From all the literature analysed and the authors' stance, no study has delved into destination countries enough to value them as pivotal and primary stakeholders in exporting companies. Minding this gap, the study contributes to the literature on stakeholder theory, with an analysis of destination countries and export performance of exported agri-food products. Only Schembri et al. (2019), analysed home country as a primary stakeholder in the field of export promotion, highlighting the participation of the home country government in export promotion, hence confirming the role of government and policy making.

The study provides a perspective on the export performance literature, demonstrating that export performance depends on both the stakeholders involved (Lages et al., 2009) and the potential role of stakeholders in performance-enhancing behaviours (Barney, 2018). The export performance of the cases studied is related to the trade agreements between the home country, in this case Chile, and the destination countries (Baier and Bergstrand, 2007; Na and Yoon, 2011; Barney, 2018).

The cases studied confirm the importance of the regulations provided by the government (Clarkson, 1995; Schembri et al., 2019), specifically the trade agreements between countries which enhance the entry of agri-food products in the destination countries (Hejazi et al., 2017). 


\section{$7 \quad$ Implications for practice}

The practical implications of this study are mainly for export firms' managers and policy makers. The results suggest that recognising the importance of interaction and integration with markets is essential.

In the context of markets with uncertainty, successful export performance relies on networks and networking, and their quality, as key activities in foreign markets. Therefore, reinforcement of the bond between international business partners, commitment to foreign markets, as well as highlighting the acquisition of knowledge and experience in these markets (Johanson and Vahlne, 1997) are pivotal. As shown above, exporting to a market with a trade agreement is important, not only to be able to face uncertain times but also to achieve greater export performance.

The implications for policy makers include the importance of trade agreements for exporting companies and for those who want to enter the international arena. Trade agreements are the responsibility of policy-makers, due to both their generation and maintenance. And in times of crisis, such as the one endured throughout COVID-19, they prove to be critical in navigating the associated dramatic and dynamic changes in markets.

\section{Acknowledgements}

The authors thank the reviewers of the International Journal of Export Marketing for their valuable insights and constructive comments on earlier versions of the manuscript.

\section{Funding}

This work was funded by the grant for Rapid Resource Allocation for Research Projects on Coronavirus (COVID-19) of the Chilean National Research Agency and Development ANID (grant number ANID-COVID0364 Concurso Asignación Rápida).

\section{References}

Agle, B.R., Mitchell, R.K. and Sonnenfeld, J.A. (1999) 'Who matters to Ceos? An investigation of stakeholder attributes and salience, corpate performance, and Ceo values', Academy of Management Journal, Vol. 42, No. 5, pp.507-525.

ASOEX (2020) Asociación de exportadores de fruta de Chile. Temporada 2020-2021: Cerezas chilenas comprometidas con entregar mayor calidad, inocuidad y seguridad a sus consumidores (Association of fruit exporters of Chile. 2020-2021 season: Chilean cherries committed to delivering higher quality, safety and security to consumers) [online] https://www.asoex.cl/component/content/article/25-noticias/846-temporada-2020-2021cerezas-chilenas-comprometidas-con-entregar-mayor-calidad-inocuidad-y-seguridad-a-susconsumidores.html (accessed 5 February 2021).

Baier, S.L. and Bergstrand, J.H. (2007) 'Do free trade agreements actually increase members' international trade?', Journal of international Economics, Vol. 71, No. 1, pp.72-95.

Barichello, R. (2020) 'The COVID-19 pandemic: anticipating its effects on Canada's agricultural trade', Canadian Journal of Agricultural Economics, Vol. 68, No. 1, pp.219-224. 
Barney, J.B. (2018) 'Why resource-based theory's model of profit appropriation must incorporate a stakeholder perspective', Strategic Management Journal, Vol. 39, No. 13, pp.3305-3325.

Bianchi, C., Carneiro, J. and Wickramasekera, R. (2018) 'Internationalisation commitment of emerging market firms: a comparative study of Chile and Brazil', Journal of Small Business and Enterprise Development, Vol. 25, No. 2, pp.201-221.

Cadogan, J.W., Diamantopoulos, A. and Siguaw, J.A. (2002) 'Export market-oriented activities: Their antecedents and performance consequences', Journal of International Business Studies, Vol. 33, No. 3, pp.615-626.

Clarkson, M.E. (1995) 'A stakeholder framework for analyzing and evaluating corporate social performance', Academy of Management Review, Vol. 20, No. 1, pp.92-117.

Conti, G., Turco, A.L. and Maggioni, D. (2014) 'Spillovers through backward linkages and the export performance of business services. Evidence from a sample of Italian firms', International Business Review, Vol. 23, No. 3, pp.552-565.

Coviello, N.E. and Munro, H.J. (1995) 'Growing the entrepreneurial firm: networking for international market development', European Journal of Marketing, Vol. 29, No. 7, pp.49-61.

Dahan, N.M., Doh, J.P. and Raelin, J.D. (2015) 'Pivoting the role of government in the business and society interface: a stakeholder perspective', Journal of Business Ethics, Vol. 131, No. 3, pp.665-680.

Dang, Q.T., Jasovska, P. and Rammal, H.G. (2020) 'International business-government relations: The risk management strategies of MNEs in emerging economies', Journal of World Business, Vol. 55, No. 1, p.101042.

Dimitrova, B.V., Korschun, D., Orschun, D. and Yotov, Y.V. (2017) 'When and how country reputation stimulates export volume', International Marketing Review, Vol. 34, No. 3, pp.377-402.

Donthu, N. and Gustafsson, A. (2020) 'Effects of COVID-19 on business and research', Journal of Business Research, Vol. 117, pp.284-289, DOI: 10.1016/j.jbusres.2020.06.008.

FAO (2019) Q\&A: COVID-19 Pandemic - Impact on Food and Agriculture [online] http://www.fao.org/2019-ncov/q-and-a/impact-on-food-and-agriculture/en/ (accessed 5 February 2021).

Freeman, R.E. (1984) Strategic Management: A Stakeholder Approach, Pitman Publishing Inc., Boston.

Gulati, R. (1995) 'Does familiarity breed trust? The implications of repeated ties for contractual choice in alliances', Academy of Management Journal, Vol. 38, No. 1, pp.85-112.

Hailu, G. (2020) 'Economic thoughts on COVID-19 for Canadian food processors', Canadian Journal of Agricultural Economics, Vol. 2020, No. 68, pp.163-169.

Hejazi, M., Grant, J.H. and Peterson, E. (2017) 'Tariff changes and the margins of trade: a case study of US agri-food imports', Journal of Agricultural and Resource Economics, Vol. 42, No. 1, pp.68-89.

Hobbs, J.E. (2020) 'Food supply chains during the COVID-19 pandemic', Canadian Journal of Agricultural Economics, Vol. 2020, No. 68, pp.171-176.

iQonsulting (2020a) Yearbook 2019/2020 International Sweet Cherry Market [online] http://www.iqonsulting.com/files/2020-Sweet-cherry-yearbook-iQonsulting.pdf (accessed 20 March 2021).

iQonsulting (2020b) Yearbook 2019/2020 International Blueberry Market [online] http://www.iqonsulting.com/files/2020-Blueberry-Yearbook-iQonsulting.pdf (accessed 20 March 2021).

iQonsulting (2021) Apple Yearbook 2021 [online] http://www.iqonsulting.com/files/2021 _iQonsulting_apple_yearbook.pdf (accessed 20 March 2021).

Ismail, N.A. and Kuivalainen, O. (2015) 'The effect of internal capabilities and external environment on small-and medium-sized enterprises' international performance and the role of the foreign market scope: the case of the Malaysian halal food industry', Journal of International Entrepreneurship, Vol. 13, No. 4, pp.418-451. 
ITC (2021) International Trade Centre [online] https://www.intracen.org/ (accessed 15 February 2021).

Johanson, J. and Vahlne, J.E. (1977) 'The internationalisation process of the firm. A model of knowledge development and increasing foreign market commitment', Journal of International Business Studies, Vol. 8, No. 1, pp.23-32.

Ker, A.P. and Cardwell, R. (2020) 'Introduction to the special issue on COVID-19 and the Canadian agriculture and food sectors: thoughts from the pandemic onset', Canadian Journal of Agricultural Economics, Vol. 2020, No. 68, pp.139-142.

Kerr, W.A. (2020) 'The COVID-19 pandemic and agriculture: Short-and long-run implications for international trade relations', Canadian Journal of Agricultural Economics/Revue canadienne d'agroeconomie, Vol. 68, No. 2, pp.225-229.

Lages, L.F., Silva, G., Styles, C. and Pereira, Z.L. (2009) 'The NEP Scale: a measure of network export performance', International Business Review, Vol. 18, No. 4, pp.344-356.

Lin, B.X. and Zhang, Y.Y. (2020) 'Impact of the COVID-19 pandemic on agricultural exports', Journal of Integrative Agriculture, Vol. 19, No. 12, pp.2937-2945.

Lu, Y., Zhou, L., Bruton, G. and Li, W. (2010) 'Capabilities as a mediator linking resources and the international performance of entrepreneurial firms in an emerging economy', Journal of International Business Studies, Vol. 41, No. 3, pp.419-436.

Na, D.S. and Yoon, Y.H. (2011) 'An empirical study of the influencing factors on export performance under the free trade agreement', Journal of International Trade, Vol. 36, No. 3, pp.23-51.

Nakat, Z. and Bou-Mitri, C. (2021) 'COVID-19 and the food industry: readiness assessment', Food Control, Vol. 2021, No. 121, p.107661121.

New Hope Nature Media (2020) Consumer Interest in Superfoods is Booming [online] https://www.newhope.com/products-and-trends/consumer-interest-superfoods-booming (accessed 6 February 2021).

Nummela, N., Vissak, T. and Francioni, B. (2020) 'The interplay of entrepreneurial and nonentrepreneurial internationalization: an illustrative case of an Italian SME', International Entrepreneurship and Management Journal, doi: 10.1007/s11365-020-00673-y.

ODEPA (2020) Comercio exterior de quesos (Foreign Trade of Cheeses) [online] https://bibliotecadigital.odepa.gob.cl/bitstream/handle/20.500.12650/70529/ArtQuesos202010. pdf? sequence $=1$ \&isAllowed $=y$ (accessed 15 February 2021).

Orden, D. (2020) 'Resilience test of the North American food system', Canadian Journal of Agricultural Economics, Vol. 2020, No. 68, pp.215-217.

Pantano, E., Pizzi, G., Scarpi, D. and Dennis, C. (2020) 'Competing during a pandemic? Retailers' ups and downs during the COVID-19 outbreak', Journal of Business Research, Vol. 116, pp.209-213, DOI: 10.1016/j.jbusres.2020.05.036.

Park, B.I. and Ghauri, P.N. (2015) 'Determinants influencing CSR practices in small and medium sized MNE subsidiaries: a stakeholder perspective', Journal of World Business, Vol. 50, No. 1, pp.192-204.

Portal Agrochile (2020) Exportación de carne bovina crece $15 \%$ en Los Lagos y tiene como principal destino a China (Bovine Meat Exports Grow 15\% in Los Lagos and its Main Destination is China) [online] https:/www.portalagrochile.cl/2020/11/05/exportacion-decarne-bovina-crece-15-en-los-lagos-y-tiene-como-principal-destino-a-china/ (accessed 9 February 2021).

Revista del Campo (2020) Exportación de carne bovina crece $15 \%$ en Los Lagos y tiene como principal destino a China (Bovine meats exports grow 15\% in Los Lagos and its main destination is China) [online] http://cache-elastic.emol.com/2020/06/15/EMSU/3I3Q7E5T /all\#213QIA1N (accessed 9 February 2021). 
Salmonexpert (2021) Valor de exportaciones de salmón chileno en 2020 disminuye 14\% (Chilean Salmon Export Value in 2020 Decreases 14\%) [online] https://www.salmonexpert.cl/ article/valor-de-exportaciones-de-salmnidos-durante-2020-disminuye-en-14/ (accessed 4 February 2021).

Schembri, J., Tang, Y.K., Fletcher, M. and Dimitratos, P. (2019) 'How do European trade promotion organisations manage their stakeholders?', International Business Review, Vol. 28, No. 6, pp.101-595.

Sheth, J. (2020) 'Impact of Covid-19 on consumer behavior: will the old habits return or die?', Journal of Business Research, Vol. 117, pp.280-283, DOI: 10.1016/j.jbusres.2020.05.059.

Sraha, G., Sharma, R.R., Crick, D. and Crick, J.M. (2020) 'International experience, commitment, distribution adaptation and performance: a study of Ghanaian firms in B2B export markets', Journal of Business \& Industrial Marketing, Vol. 15, No. 11, pp.1715-1738.

SUBREI (2020) Comercio Exterior de Chile enero a septiembre de 2020. Subsecretaria de Relaciones Económicas Internacionales Dirección de Estudios (Chile's Foreign Trade January to September 2020. Under Secretariat for International Economic Relations Directorate of Studies) [online] https://www.subrei.gob.cl/docs/default-source/estudios-ydocumentos/reporte-trimestral/informe-tercer-trimestre-2020.pdf?sfvrsn=a7f128d9_1 (accessed 5 February 2021).

Vasylieva, N. and James, H. (2021) 'Production and trade patterns in the world apple market', Innovative Marketing, Vol. 17, No. 1, pp.16-25.

Vissak, T. (2010) 'Recommendations for using the case study method in international business research', Qualitative Report, Vol. 15, No. 2, pp.370-388.

Vissak, T., Francioni, B. and Freeman, S. (2020) 'Foreign market entries, exits and re-entries: the role of knowledge, network relationships and decision-making logic', International Business Review, Vol. 29, No. 1, pp.101-592.

WTO (2020) Trade Set to Plunge as COVID-19 Pandemic Upends Global Economy [online] https://www.wto.org/english/news_e/pres20_e/pr855_e.htm (accessed 20 December 2020).

Yin, R.K. (1994) Case Study Research Design and Methods, Sage, London.

\section{Appendix}

Table A1 HS-code chapter and subheadings of exported agri-food products

\begin{tabular}{|c|c|c|}
\hline HS chapter & Chapter description & Subheading HS-code \\
\hline 02 & Meat and edible meat offal & 020220,020230 \\
\hline 03 & $\begin{array}{l}\text { Fish and crustaceans, molluscs and other aquatic } \\
\text { invertebrates }\end{array}$ & $\begin{array}{c}\text { 030214, 030312, } \\
\text { 030313, 030441, } \\
030481,030482,030499\end{array}$ \\
\hline 04 & $\begin{array}{l}\text { Dairy produce; birds' eggs; natural honey; edible } \\
\text { products of animal origin, not elsewhere specified or } \\
\text { included }\end{array}$ & 040410,040690 \\
\hline 08 & Edible fruit and nuts; peel of citrus fruits or melons & $080810,080929,081040$ \\
\hline 11 & $\begin{array}{l}\text { Products of the milling industry; malt; starches; } \\
\text { inulin; wheat gluten }\end{array}$ & 110412,110422 \\
\hline 16 & $\begin{array}{l}\text { Preparation of meat, of fish or of crustaceans, } \\
\text { molluscs or other aquatic invertebrates }\end{array}$ & 160553 \\
\hline 20 & $\begin{array}{l}\text { Preparations of vegetables, fruit, nuts or other parts of } \\
\text { plants }\end{array}$ & 200893, 200981 \\
\hline
\end{tabular}


Table A2 Number of export companies involved in cases studied, and export value as a \% of total export value of the HS-code chapter

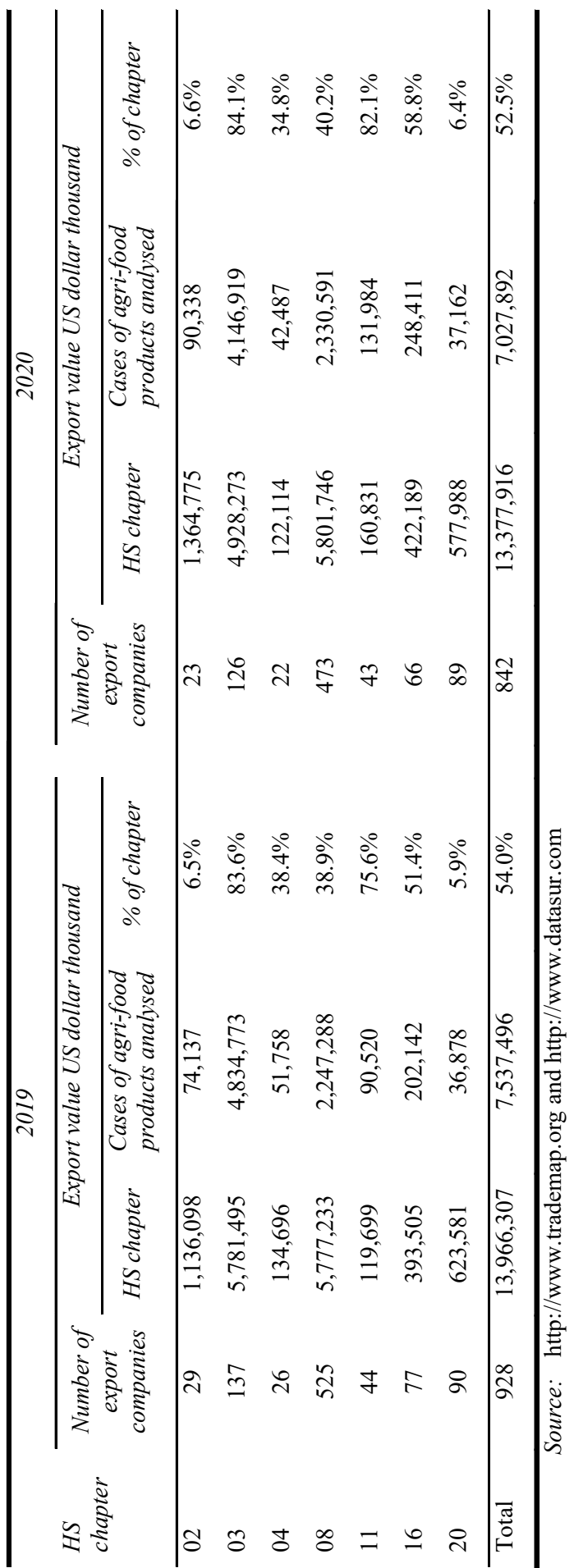


Table A3 Export performance of exported agri-food products by HS-code

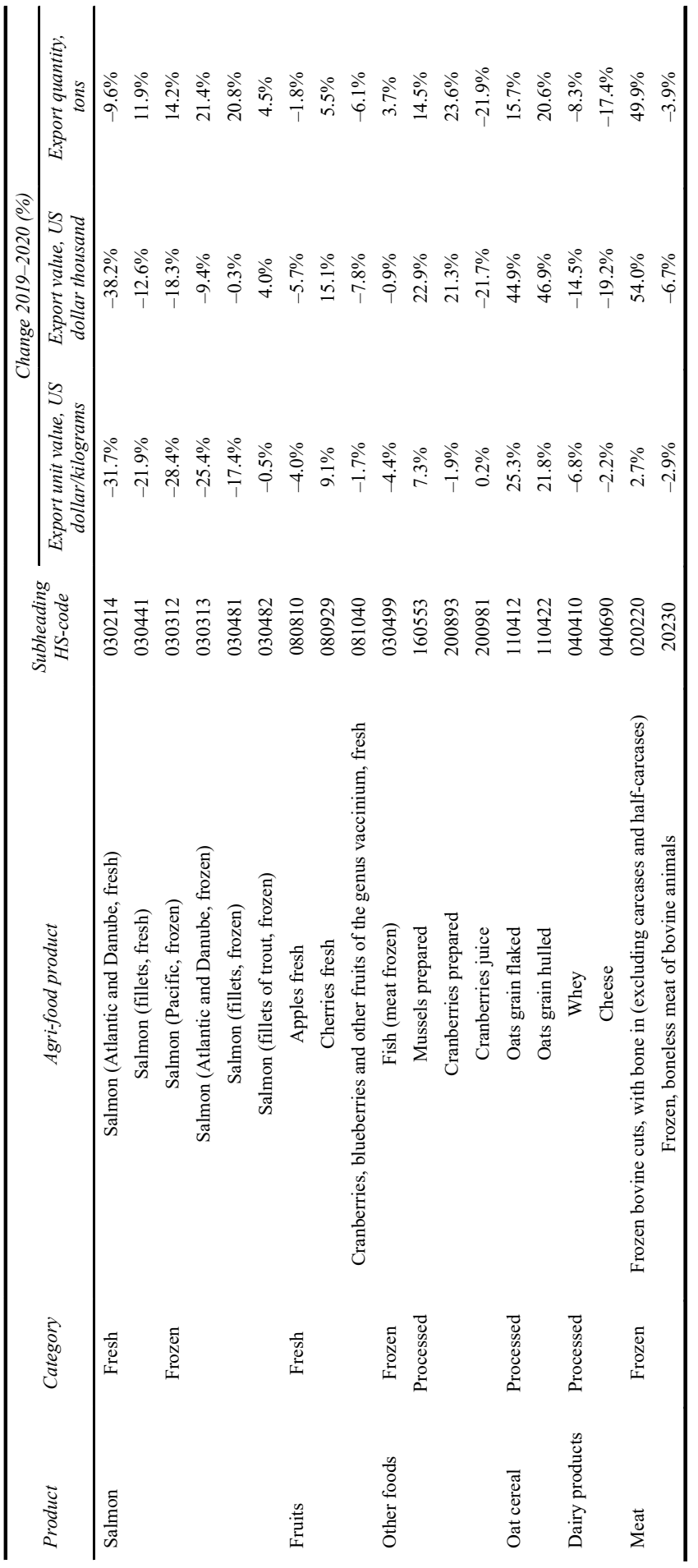

